\title{
Nematode capilaridae in the tongue of Cerdocyon thous of free life in Brazil
}

\author{
Nematoide capilaridae na língua de Cerdocyon thous de vida livre no Brasil \\ Raul Henrique da Silva Pinheiro ${ }^{1}$; Isabella Bittencourt Pires Chaves ${ }^{2}$; Rogério Antonio Ribeiro Rodrigues ${ }^{1}$, \\ Érika Branco ${ }^{2}$; Ana Rita de $\mathrm{Lima}^{2}$; Elane Guerreiro Giese ${ }^{1 *}$

\begin{abstract}
${ }^{1}$ Laboratório de Histologia e Embriologia Animal, Instituto da Saúde e Produçáo Animal, Universidade Federal Rural da Amazônia UFRA, Belém, PA, Brasil

${ }^{2}$ Laboratório de Pesquisa Morfológica Animal, Instituto da Saúde e Produção Animal, Universidade Federal Rural da Amazônia UFRA, Belém, PA, Brasil
\end{abstract}

Received July 18, 2018

Accepted September 05, 2018

\begin{abstract}
Studies of helminths in road-killed wild animals are still uncommon but may provide promising results since they can identify the parasites in juvenile and adult hosts and meet the recommendations of current discussions on bioethics that prioritize alternative methods for the use of animals. This study evaluated three Cerdocyon thous individuals that were donated after dying from being run over. Two of them had small nematode adults in the epithelial and connective tissues of the tongue. The diagnosis was based on the presence of eggs, observed in histological sections, and morphological characteristics of the nematodes in the tongue. Morphologically, this nematode has a body with transverse grooves, simple mouth opening and no lips, esophagus and stichosome with stichocytes and bacillary bands along the body, which is characteristic morphology of the family Capilariidae and genus Capillaria. The presence of this nematode in the tongue of $C$. thous is an extremely important fact that contributes to what is known about the biodiversity of zoonotic parasites in wild canid populations. However, an explanation for these findings remains unclear because, until now, this has not been observed in the biological cycle of the species.
\end{abstract}

Keywords: Nematoda, Capillaria, mammal, Amazon.

\section{Resumo}

O estudo de helmintos de animais selvagens vitimados por atropelamento, ainda é uma prática pouco comum, porém pode ser promissor, uma vez que permite a identificaçáo de helmintos a partir de hospedeiros juvenis e adultos, e atendem às atuais discussóes em bioética, as quais priorizam métodos alternativos para o uso de animais. Foram avaliados 3 exemplares de Cerdocyon thous provenientes de doação pós-óbito por atropelamento. Dois deles apresentaram pequenos nematoides adultos inseridos nos tecidos epitelial e conjuntivo da língua. O diagnóstico foi baseado na análise de cortes histológicos que evidenciaram a presença de ovos no interior do nematoide e nas características morfológicas gerais do mesmo. Morfologicamente estes nematoides apresentavam corpo com estrias transversais, abertura bucal simples e lábios ausentes, esôfago trichuroiude com a presença de esticócitos e bandas bacilares ao longo do corpo, característica morfologicamente sugestiva da família Capillariidae e do gênero Capillaria. A presença de nematoides inseridos na língua de C. thous é um fato de extrema importância para o conhecimento da biodiversidade de parasitos zoonóticos circulantes presentes em populaçóes selvagens de canídeos. Porém, permanece obscura a explicação para tais achados, uma vez que tal evento náo foi observado no ciclo biológico das espécies até o momento.

Palavras-chave: Nematoda, Capillaria, mamífero, Amazônia.

\footnotetext{
*Corresponding author: Elane Guerreiro Giese. Laboratório de

Histologia e Embriologia Animal, Instituto da Saúde e Produção Animal,

Universidade Federal Rural da Amazônia - UFRA, Av. Presidente

Tancredo Neves, 2501, Terra Firme, CEP 66077-830, Belém, PA, Brasil.

e-mail: elane.giese@ufra.edu.br
} 


\section{Introduction}

Studies involving the helminthofauna of wild animals are of great importance for the conservation of species and for public health, since some of these parasites can injure wild populations and have zoonotic potential (LAFFERTY, 1997).

Some helminths that parasitize wild mammals belong to the family Capillaridae. The taxonomy of this family is still being revised and the group contains many species in the genus Capillaria (GUARDONE et al., 2013; FUEHRER, 2014), of which Capillaria hepatica Bancroft, 1893 is the most commonly cited in the literature as a parasite of various domestic and wild animals (FREITAS \& LENT, 1936; ARAÚJO, 1967; SILVEIRA et al., 1975; GALVÁO, 1981; CHIEFFI et al., 1981; MANDORINO \& REBOUÇAS, 1991; VICENTE et al., 1997; RUAS et al., 2003). Capillaria comprises a complex group of parasites, which has resulted in the proposal of the genera Calodium, Eucoleus, Paracapillaria, Pearsonema and Aonchotheca (GUARDONE et al., 2013; FUEHRER, 2014). Within this complex, three species are of zoonotic importance: Paracapillaria philippinensis (Syn. Capillaria philippinensis), Eucoleus aerophila (Syn. Capillaria aerophila) and Calodium hepaticum (Syn. Capillaria hepatica, Trichocephalus hepaticus Bancroft, 1893 and Hepaticola hepatica Hall 1916.

Due to anthropic impacts, wild animals frequently come out of natural habitats in search of food and suffer injuries. Roads, starting at the construction phase, impact native fauna in several ways, producing direct and indirect effects on populations, such as mortality from being run over, loss of habitat, dispersion of exotic species and intensification of the presence of humans (ASCENSÃO \& MIRA, 2006). The study of helminths in road-killed animals is still uncommon; however, studies that use this methodology are promising since they can identify these parasites in adults and young individuals and meet the recommendations of current discussions on bioethics that prioritize alternative methods for the use of animals (RICHINI-PEREIRA et al., 2006). In Brazil, among the wild carnivores, Cerdocyon thous is one of the most commonly road-killed species (MALHEIROS, 2004; PRADA, 2004; PINOWSKI, 2005).

Based on the few studies about the presence of capillariids in wild animals, this study describes the first record in Brazil of a Capillariidae nematode parasitizing the tongue of $C$. thous, in the municipality of Paragominas in Pará State, in addition to collecting and analyzing retrospective data on the fauna of helminths of C. thous in Brazil.

\section{Materials and Methods}

We evaluated the tongues of three animals ( $C$. thous) that were donated, after being run over by the company HYDRO Paragominas - bauxite mine, to the Laboratório de Pesquisa Morfológica Animal (LaPMA) - Instituto da Saúde e Produção Animal at the Universidade Federal Rural da Amazônia (UFRA), campus Belém (under authorization of SEMA-PA No 455/2009 and 522/2009), animals used for morphological studies.
To extract the tongues, used in morphological studies by LaPMA, an incision in the skin and muscles of the mentonian region was made. The tongue was folded ventrally after cutting the lingual frenulum and then cut caudally at the root to harvest the material. The material was fixed in a $10 \%$ formaldehyde solution for the histological analysis and in an AFA solution (93 parts 70\% ethyl alcohol, 5 parts formaldehyde, and 2 parts glacial acetic acid) for the morphological analysis. Samples of the nematodes were separated from the lingual tissue, dehydrated in an ethanol series, clarified with lactophenol, placed on a microscope slide under a coverslip as a temporary mount, observed using a light microscope, and photographed with a LEICA DM2500 microscope with an image capturing system. This work was conducted in the Laboratório de Histologia e Embriologia Animal - Instituto da Saúde e Produção Animal. For scanning electron microscopy, fragments of the tongue with nematodes were fixed in $10 \%$ formaldehyde, post-fixed in $1 \%$ osmium tetroxide, critical point dried with $\mathrm{CO}_{2}$, coated with gold-palladium and analyzed with a VEGA 3 LMU/TESCAN scanning electron microscope. This was done in the Laboratório de Microscopia Eletrônica de Varredura - Instituto da Saúde e Produção Animal at the Universidade Federal Rural da Amazônia (UFRA), campus Belém. To avoid confusion, only names of genera of helminths are abbreviated and not those of hosts.

\section{Results}

Of the three animals evaluated, two had six small adult nematodes in the epithelial and conjunctive tissues of the tongue (Figure 1A and 2A-C). The six nematodes formed galleries within the epithelium (Figure 1D- E and 2B) and their dispersal had a multifocal character. The diagnosis was based on the presence of eggs (FERRER \& CASTELLÀ, 1996), observed in histological sections, and morphological characteristics of the nematodes in the tongues, which were analyzed using scanning electron microscopy (body surface) and light microscopy

During the histological analysis of the $C$. thous tongues, adult female nematodes were observed in transverse sections. These were inserted in the basal layers of stratified epithelial tissue, with eggs both inside the parasite as well as egg isolates and clusters within galleries developed by the nematodes (Figure 1D-E). The eggs were barrel shaped with two polar opercula with plugs on the ends, which are diagnostic characteristics of the genus Capillaria (Figure 1B-C). The size and the number of nematodes inserted in the tegument of the coating of the tongue did not cause inflammatory reactions and did not affect the morphology of the lingual papillae (Figure 1D).

A light microscopy analysis of a fragment of a nematode, clarified with Amman's lactophenol, was conducted on the anterior region of the helminth because the rest of the body was strongly inserted in the tissue and it was not possible to completely remove the parasite (Figure 3A-B). Morphologically, the nematodes have a body with transverse grooves, a simple mouth opening and no lips, stichosome esophagus formed by stichocytes and bacillary bands (Figure 2D) on the surface of the cuticle along the body, which are also morphological characteristics of Capillaria (Figure 3A-B). 

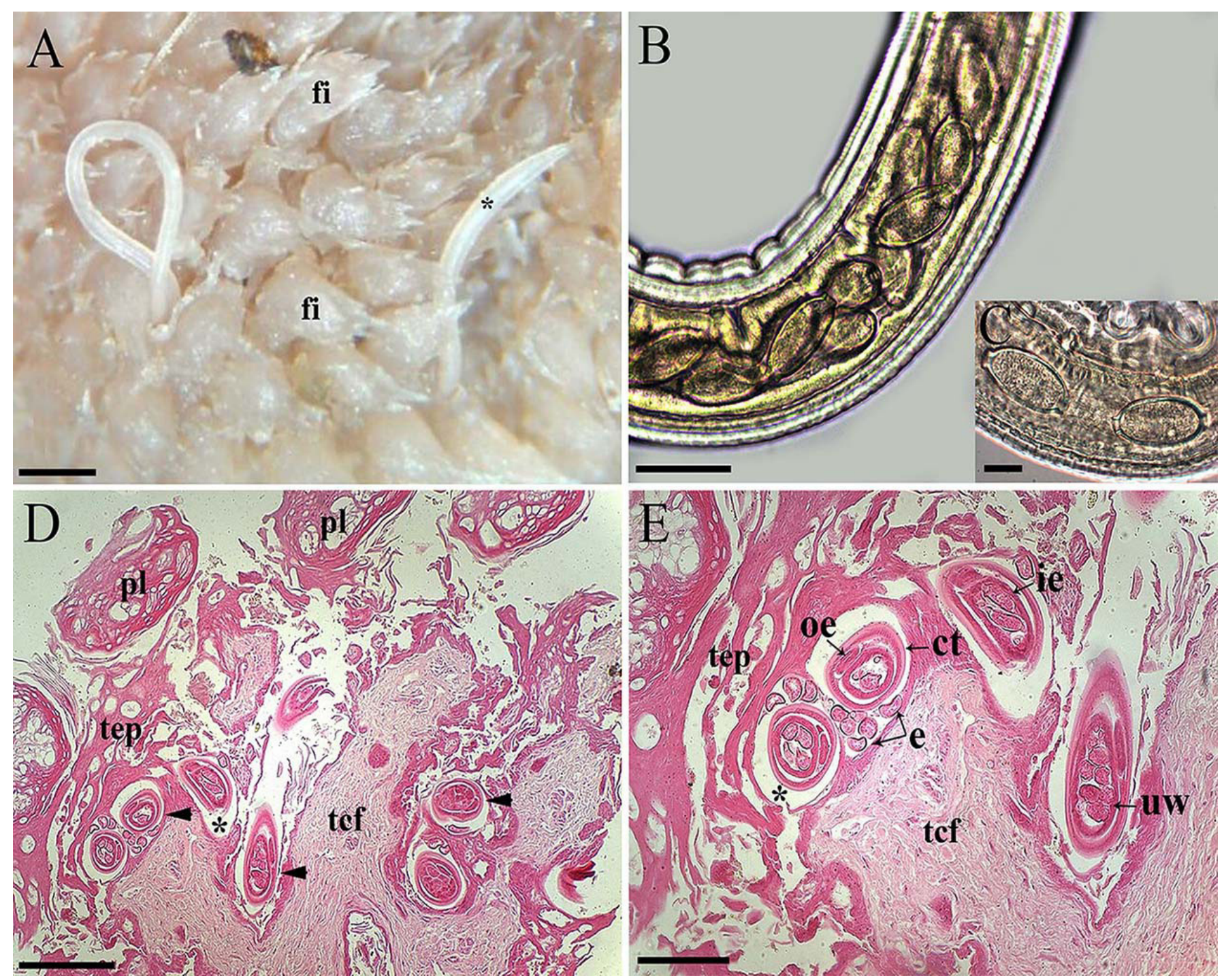

Figure 1. (A) Mesoscopic view of Capillaria sp. $\left(^{*}\right)$ inserted among the lingual filiform papillae (fi) of Cerdocyon thous in Pará State. (B) Lateral view of the Capillaria sp. female showing numerous intrauterine eggs. (C) Detail of eggs morphology with barrel shaped and two polar opercula with plugs on the ends. (D-E) Tongue photomicrographs of C. thous parasitized by Capillaria sp., in Pará State, stained with hematoxilin and eosin. (D) Lingual papillae (pl), sustained to loose connective tissue (tcf) and covered by keratinized stratified flat epithelial tissue (tep), where the Capillaria sp. (arrowhead) are inserted in interstitial space $\left(^{*}\right)$. (E) Cut of Capillaria sp. in keratinized stratified flat epithelial tissue (tep), sustained to loose connective tissue (tcf). Detail of cut of the nematode evidencing the cuticle (ct), uterine wall (uw), intrauterine eggs (ie), oesophagus (oe) and eggs (e) in the intertitial space $\left(^{*}\right)$. Scale bars: $A=1.5 \mathrm{~cm}, \mathrm{~B}=50 \mu \mathrm{m}, \mathrm{C}=20 \mu \mathrm{m}, \mathrm{D}=200 \mu \mathrm{m}, \mathrm{E}=100 \mu \mathrm{m}$.

\section{Discussion}

In studies of the nematofauna of $C$. thous, published between 1915 and 2017, adult and juvenile nematodes in 13 superfamilies (Ancylostomatoidea, Ascaridoidea, Dioctophymatoidea, Filarioidea, Metastrongyloidea, Oxyuroidea, Physalopteroidea, Rictularoidea, Rhabditoidea, Strongyloidea, Spiruroidea, Thichinelloidea, Trichostrongloidea) were recorded in 13 localities in Brazil (Table 1). Of these, 15 families, 18 genera and 24 species of nematodes were identified. Some taxa were not identified to the specific level because the authors only conducted coprological exams. In the cases described as morphotypes, the authors provided morphological characteristics of the eggs (when possible) and/or measurements of the parasite; due to the lack of data, these were classified only as phylum Nematoda (Table 2).

The nematodes found in the tongue of Cerdocyon thous, collected in the municipality of Paragominas, Pará State, in eastern Amazon, have similar characteristics to those of other species of the family Capillaridae Railliet, 1915, and genus Capillaria Zeder, 1800. The diagnosis of infection by Capillaria in this study is based on the presence of eggs with bipolar plugs, as well as the morphological characteristics of the nematodes found in the tongue. Capillariidae, one of the five families belonging to the superfamily Trichinellidea, comprise more than 300 known species 

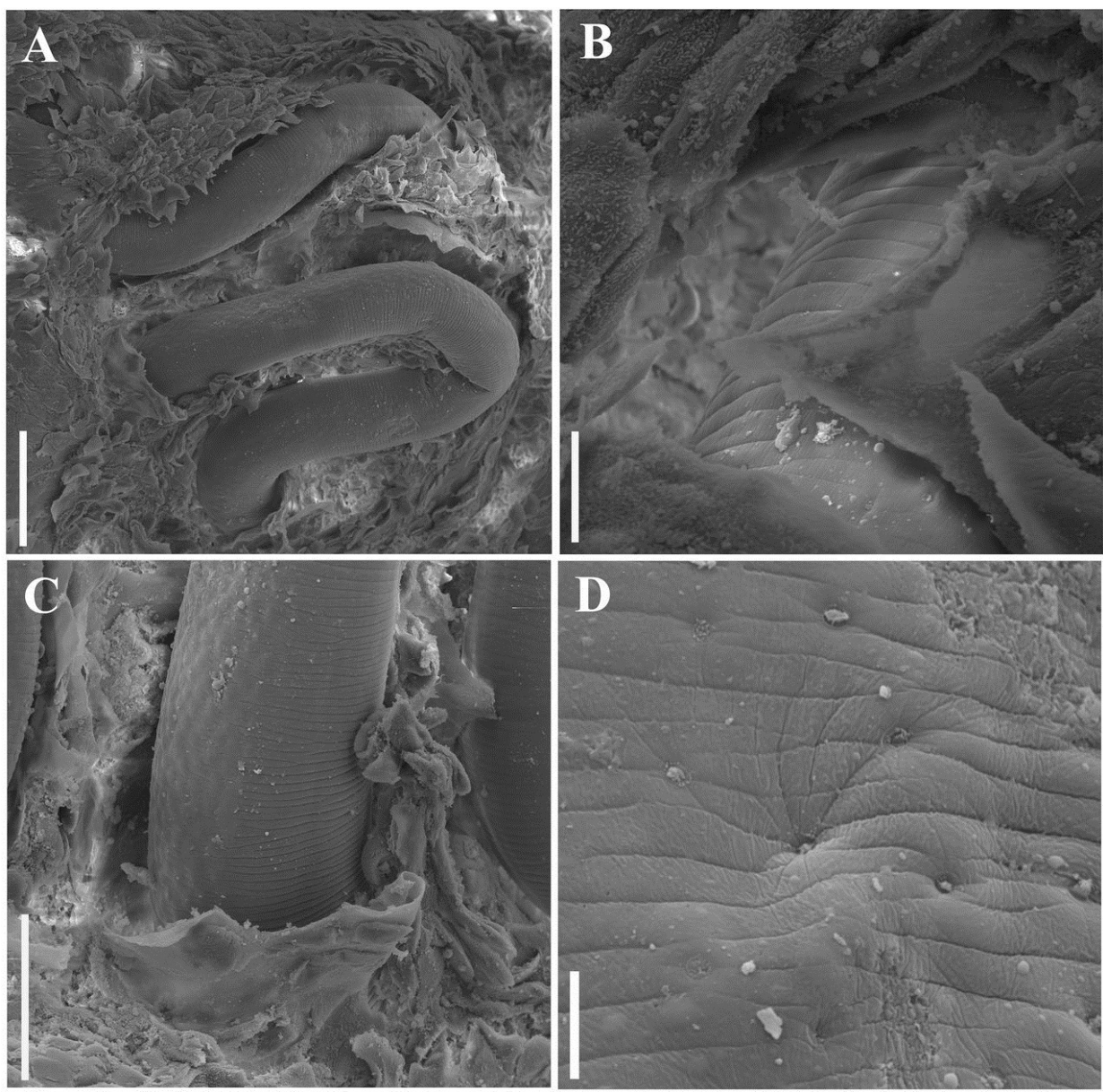

Figure 2. Scanning electron microscopy of Capillaria sp. parasitizing the tongue of $C$. thous in Pará State. (A) Overview of the parasite inserted between the lingual papillae. (B) Detail of Capillaria sp. inserted in the interstitial space formed by keratinized, stratified, flat epithelial tissue. (C) Detail of the posterior region of the nematode strongly inserted in the keratinized, stratified, flat epithelial tissue of the tongue. (D) Detail of the bacillary bands present along the body of the nematode. Scale bars: $A=100 \mu \mathrm{m}, \mathrm{B}=10 \mu \mathrm{m}, \mathrm{C}=50 \mu \mathrm{m}, \mathrm{D}=5 \mu \mathrm{m}$.
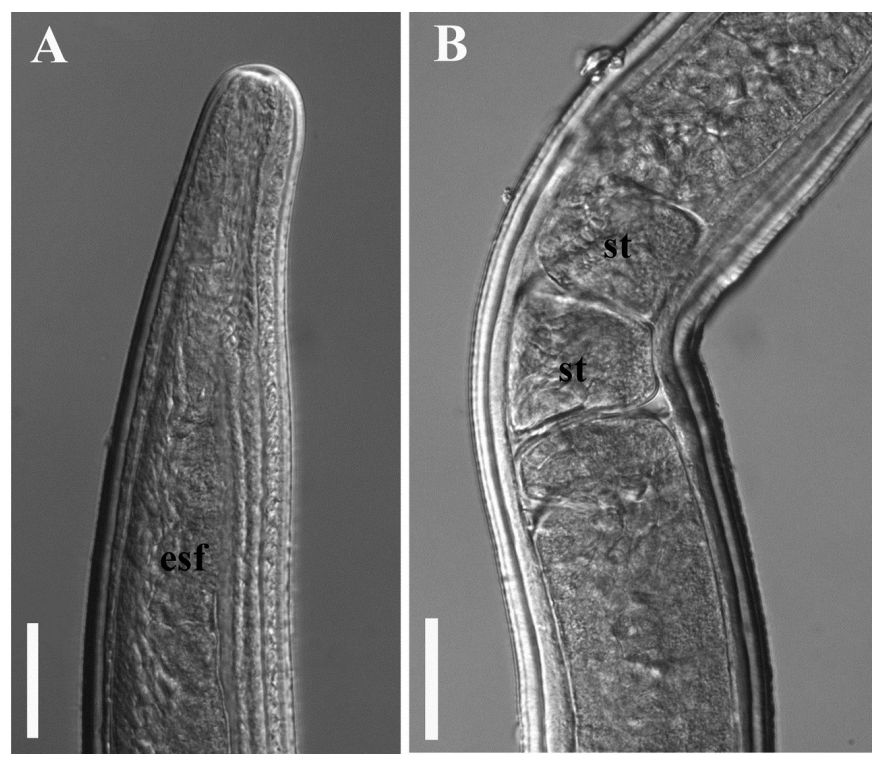

Figure 3. Photomicrographs of Capillaria sp. parasitizing the tongue of $C$. thous in Pará State. (A) Overview off anterior region in lateral position, simple oral opening with no lips and initial portion of stichosome esophagus (esf); (B) Lateral view of the middle region of Capillaria sp. showing the presence of stichocytes (st). Scale bars: $A=50 \mu \mathrm{m}, \mathrm{B}=50 \mu \mathrm{m}$. 


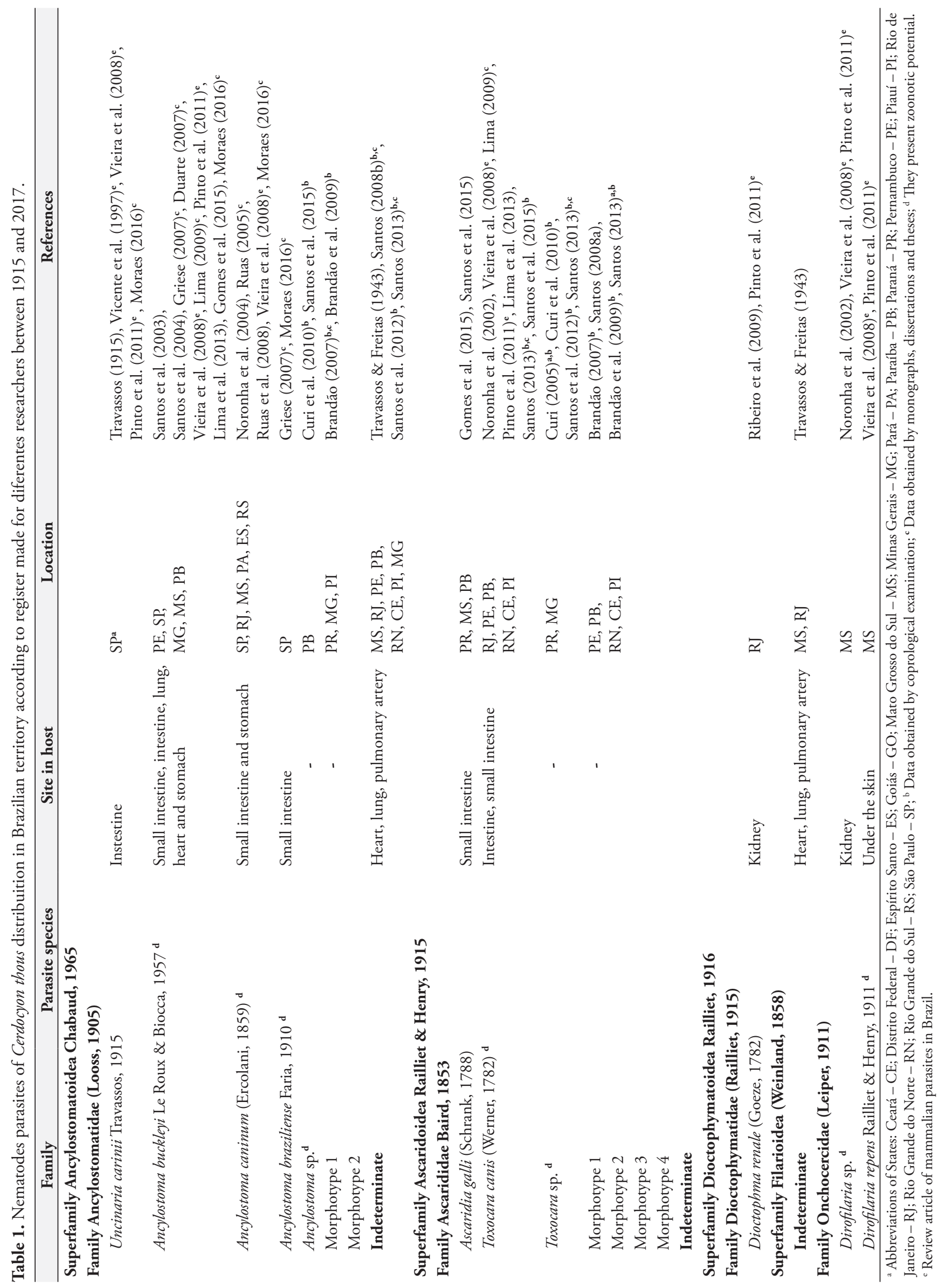




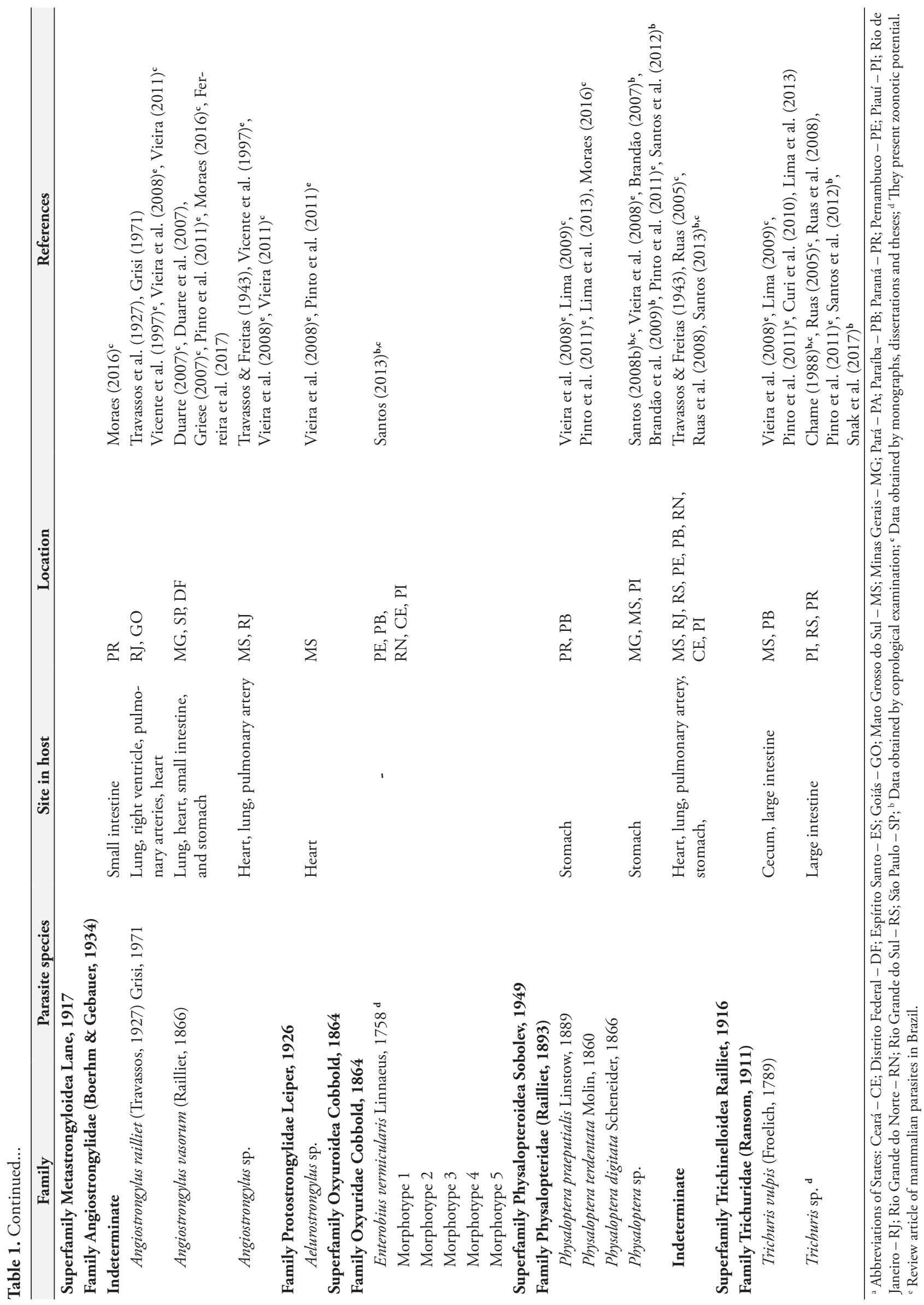




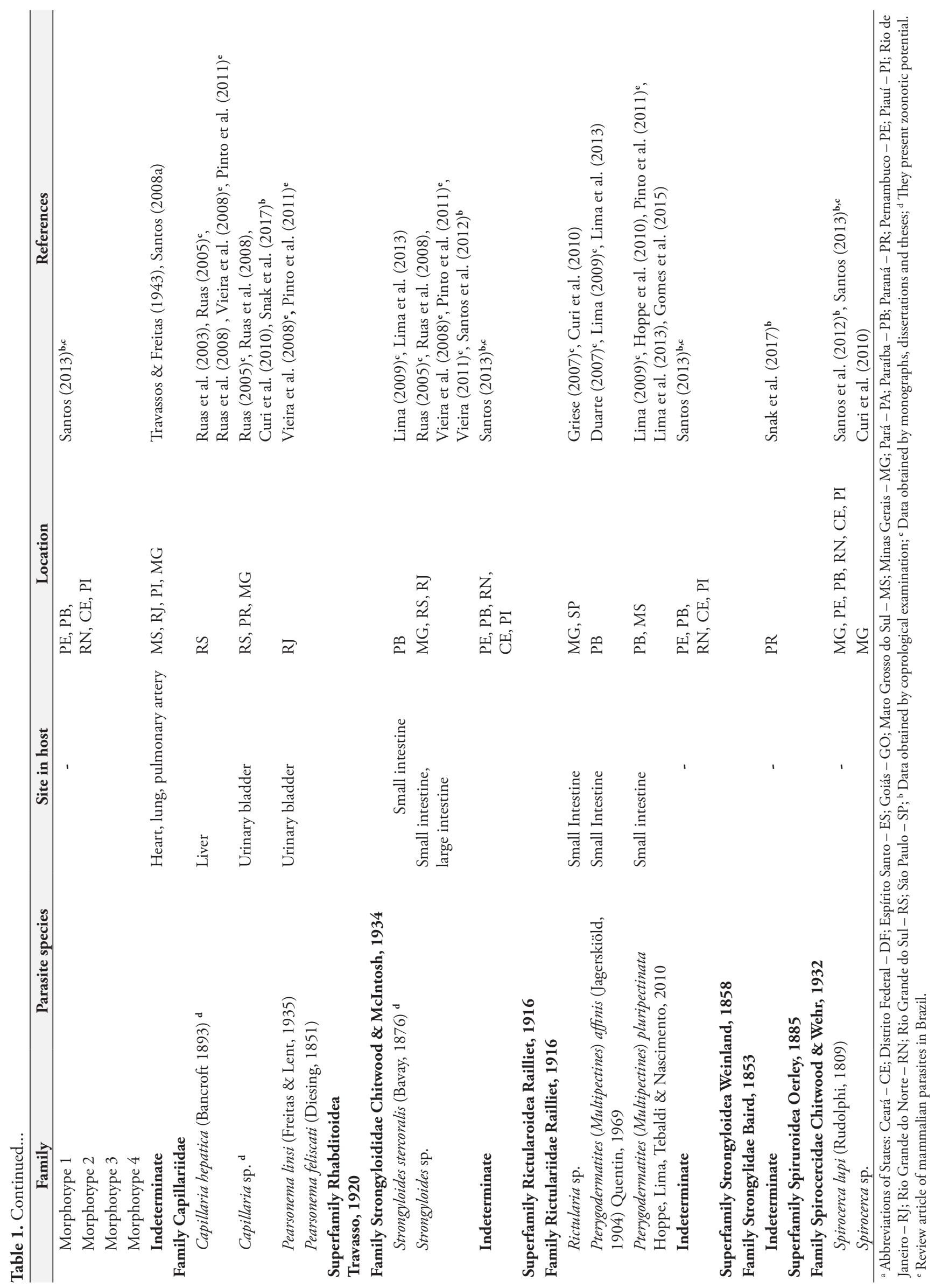




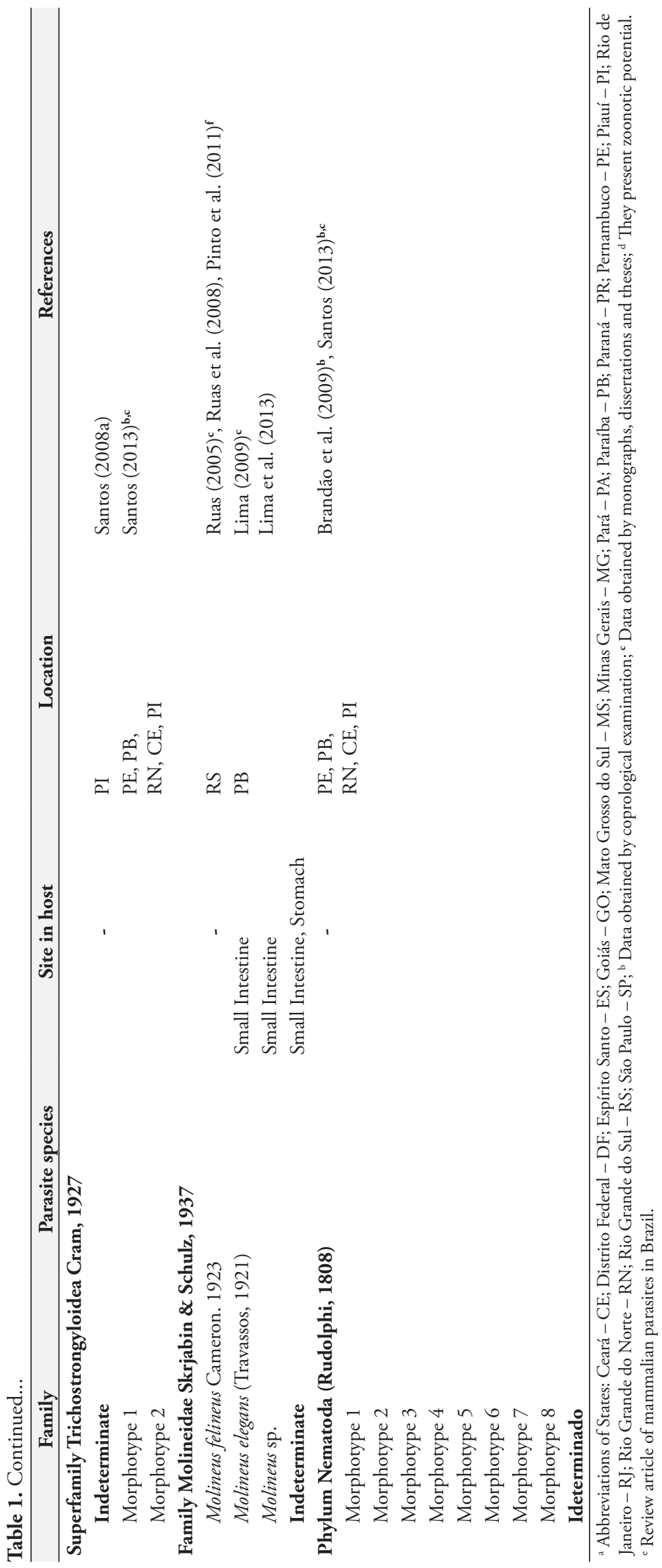


Table 2. Morphological description of egg morphotypes found in Cerdocyon thous, in Brazil, according to different studies conducted between 1915 and 2017.

\begin{tabular}{|c|c|c|c|}
\hline Parasite species & Morphological characteristics & Measurement $(\mu \mathrm{m})$ & References \\
\hline \multicolumn{4}{|c|}{ Superfamily Ancylostomatoidea Chabaud, 1965} \\
\hline \multicolumn{4}{|c|}{ Family Ancylostomatidae (Looss, 1905) } \\
\hline Ancylostoma buckleyi & Not reported & $108 \times 83$ & Santos et al. (2003) \\
\hline Morphotype 1 & $\begin{array}{l}\text { Oval shape, shell double, thin and smooth, poles big and } \\
\text { round }\end{array}$ & $56.5 \times 38.5$ & \multirow{2}{*}{$\begin{array}{l}\text { Brandão (2007), } \\
\text { Brandão et al. } \\
(2009)\end{array}$} \\
\hline Morphotype 2 & Elliptical shape, shell smooth, poles uneven & $59 \times 39$ & \\
\hline Morphotype 3 & $\begin{array}{l}\text { Elliptical or round shape, shell single, thin, smooth and } \\
\text { transparent, embryo morulate or larvae well developed }\end{array}$ & $58.5 \times 40$ & Santos (2013) \\
\hline Indeterminate & Not reported & $54 \times 33$ & Santos (2008b) \\
\hline \multicolumn{4}{|c|}{ Ascaridoidea Railliet \& Henry, 1915} \\
\hline \multicolumn{4}{|c|}{ Ascarididae Baird, 1853} \\
\hline \multirow[t]{2}{*}{ Toxocara sp. } & Not reported & $71 \times 42.5$ & Santos (2008b) \\
\hline & $\begin{array}{l}\text { Round shape, shell thick and covered by a rugged and ornate } \\
\text { outer shell, embryonic mass in development or larvae well } \\
\text { developed }\end{array}$ & $85 \times 76$ & Santos (2013) \\
\hline Morphotype 1 & Not reported & $31 \times 20$ & \multirow[t]{2}{*}{ Santos (2008a) } \\
\hline Morphotype 2 & Not reported & $46 \times 28$ & \\
\hline Morphotype 3 & Elliptical shape, shell rough & $61 \times 36$ & Brandão (2007), \\
\hline Morphotype 4 & Oval or round shape, shell double and irregularly thick & $65 \times 7$ & $\begin{array}{l}\text { Brandão et al. } \\
(2009)\end{array}$ \\
\hline Morphotype 5 & $\begin{array}{l}\text { Elliptical shape, shell thick and smooth, embryonic mass in } \\
\text { development }\end{array}$ & $67 \times 46$ & Santos (2013) \\
\hline \multicolumn{4}{|c|}{ Superfamily Trichinelloidea Railliet, 1916} \\
\hline \multicolumn{4}{|c|}{ Family Trichuridae (Ransom, 1911) } \\
\hline \multirow{2}{*}{ Trichuris sp. } & Not reported & $57 \times 27$ & Chame (1988) \\
\hline & Not reported & $57 \times 25$ & Santos (2008a) \\
\hline Indeterminate & Not reported & $59 \times 31$ & \\
\hline Indeterminate & Not reported & $64 \times 28.6$ & Santos (2008b) \\
\hline Morphotype 1 & $\begin{array}{l}\text { Barrel shape, two polar opercula slightly flattened, shell thin, } \\
\text { smooth and brown, embryonic mass in development }\end{array}$ & $55 \times 25$ & Santos (2013) \\
\hline Morphotype 2 & $\begin{array}{l}\text { Barrel shape, two opercula unequal and little prominent, } \\
\text { shell thin and clear, embryonic mass, large compared to the } \\
\text { rest of this family }\end{array}$ & $82.5 \times 37.5$ & \\
\hline Morphotype 3 & $\begin{array}{l}\text { Barrel shape, two polar opercula symmetric, shell thick, dark } \\
\text { brown, embryonic mass or larvae well developed }\end{array}$ & $80 \times 38$ & \\
\hline Morphotype 4 & $\begin{array}{l}\text { Barrel shape, two polar opercula symmetric and prominent, } \\
\text { light brown, shell thick and smooth, embryonic mass in } \\
\text { development }\end{array}$ & $58 \times 28$ & \\
\hline \multicolumn{4}{|l|}{ Family Capillariidae } \\
\hline Capillaria hepatica & - & $59 \times 31$ & Ruas et al. (2003) \\
\hline \multicolumn{4}{|c|}{ Superfamily Physalopteroidea Sobolev, 1949} \\
\hline \multicolumn{4}{|c|}{ Family Physalopteridae (Railliet, 1893) } \\
\hline Physaloptera tendernata & Ellipsoidal shape, shell thin & $27 \times 16$ & Lima (2009) \\
\hline Physaloptera praeputialis & Ellipsoidal shape, shell thin - In utero & $27 \times 23$ & \\
\hline \multirow{2}{*}{ Physaloptera sp. } & Not reported & $36 \times 28$ & Santos (2008b) \\
\hline & $\begin{array}{l}\text { Elliptical to round shape, shell thick and smooth, containing } \\
\text { larvae }\end{array}$ & $43 \times 25$ & $\begin{array}{l}\text { Brandáo et al. } \\
\text { (2009) }\end{array}$ \\
\hline Indeterminate & Not reported & $51 \times 30$ & Santos (2008a) \\
\hline Indeterminate & $\begin{array}{l}\text { Elliptical shape, shell single, thick and smooth, larvae well } \\
\text { formed }\end{array}$ & $57 \times 35$ & Santos (2013) \\
\hline \multicolumn{4}{|c|}{ Superfamily Rhabditoidea Travassos, 1920} \\
\hline \multicolumn{4}{|c|}{ Family Strongyloididae Chitwood \& McIntosh, 1934} \\
\hline Indeterminate & $\begin{array}{l}\text { Elliptical or rounded shape, shell single, smooth, thin and } \\
\text { transparent, larvae formed }\end{array}$ & $54 \times 28$ & Santos (2013) \\
\hline
\end{tabular}


Table 2. Continued...

\begin{tabular}{|c|c|c|c|}
\hline Parasite species & Morphological characteristics & Measurement $(\mu \mathrm{m})$ & References \\
\hline \multicolumn{4}{|c|}{ Superfamily Strongyloidea Weinland, 1858} \\
\hline \multicolumn{4}{|c|}{ Family Strongylidae Baird, 1853} \\
\hline Indeterminate & Not reported & & Snak et al. (2017) \\
\hline \multicolumn{4}{|c|}{ Superfamily Spiruroidea Oerley, 1885} \\
\hline \multicolumn{4}{|c|}{ Family Spirocercidae Chitwood \& Wehr, 1932} \\
\hline \multirow[t]{2}{*}{ Spirocerca lupi } & Not reported & $25.5 \times 8.5$ & Santos $(2008 b)$ \\
\hline & $\begin{array}{l}\text { Elliptical shape and small size, shell thick and smooth, larvae } \\
\text { well developed }\end{array}$ & $36 \times 14$ & Santos (2013) \\
\hline \multicolumn{4}{|c|}{ Superfamily Trichostrongyloidea Cram, 1927} \\
\hline Indeterminate & & $40 \times 18$ & Santos (2008a) \\
\hline Morfotipo 1 & $\begin{array}{l}\text { Elliptical shape, long and thin, shell thin and smooth, } \\
\text { one side slightly convex and the other concave, larvae well } \\
\text { developed }\end{array}$ & $54 \times 19$ & Santos (2013) \\
\hline Morfotipo 2 & $\begin{array}{l}\text { Elliptical shape and larger, shell thin, transparent and } \\
\text { smooth, larvae well developed }\end{array}$ & $65 \times 29$ & \\
\hline \multicolumn{4}{|c|}{ Family Molineidae Skrjabin \& Schulz, 1937} \\
\hline Molineus sp. & Elliptical shape & $42 \times 16$ & Lima (2009) \\
\hline Indeterminate & Not reported & $60 \times 25$ & \\
\hline \multicolumn{4}{|c|}{ Superfamily Rictularoidea Railliet, 1916} \\
\hline \multicolumn{4}{|c|}{ Family Rictulariidae Railliet, 1916} \\
\hline Pterygodermatites pluripectinata & Dairy eggs - In utero & $39 \times 28.5$ & Lima (2009) \\
\hline Pterygodermatites affinis & Dairy eggs - In utero & $25 \times 17$ & \\
\hline Indeterminate & $\begin{array}{l}\text { Round shape, shell smooth, simple and thick, larvae well } \\
\text { formed }\end{array}$ & $40 \times 31$ & Santos (2013) \\
\hline \multicolumn{4}{|c|}{ Superfamily Oxyuroidea Cobbold, 1864} \\
\hline \multicolumn{4}{|c|}{ Family Oxyuridae Cobbold, 1864} \\
\hline Enterobius vermicularis & $\begin{array}{l}\text { Asymmetric shape, shell smooth, simple and transparent, } \\
\text { larvae developed, poles unequal, one sharper and one more } \\
\text { rounded }\end{array}$ & $60 \times 32$ & Santos (2013) \\
\hline Morphotype 1 & $\begin{array}{l}\text { Asymmetric shape, dark brown, simple and fluted mem- } \\
\text { brane, embryonic mass, sometimes with developed larvae }\end{array}$ & $87 \times 48$ & \\
\hline Morphotype 2 & $\begin{array}{l}\text { Asymmetric shape, light brown or coppery, larvae robust } \\
\text { and well formed, apparently with two thin membranes in } \\
\text { the shell }\end{array}$ & $132 \times 63$ & \\
\hline Morphotype 3 & $\begin{array}{l}\text { Asymmetric shape, light brown or coppery, larvae robust, } \\
\text { very similar to morphotype } 2 \text {, but slightly larger in size }\end{array}$ & $185 \times 83$ & \\
\hline Morphotype 4 & $\begin{array}{l}\text { Asymmetric shape, light brown or yellowish, shell simple } \\
\text { and thin, larvae well developed }\end{array}$ & $212 \times 93$ & \\
\hline Morphotype 5 & $\begin{array}{l}\text { Asymmetric shape, shell double and thin, colorless, larvae in } \\
\text { formation }\end{array}$ & $99 \times 43$ & \\
\hline \multicolumn{3}{|c|}{ Phylum Nematoda (Rudolphi, 1808) } & \multirow{9}{*}{$\begin{array}{l}\text { Santos (2008a), } \\
\text { Brandáo et al. } \\
\text { (2009), Santos } \\
\text { (2013) }\end{array}$} \\
\hline Morphotype 1 & Not reported & $44 \times 22.5$ & \\
\hline Morphotype 2 & Not reported & $27 \times 14$ & \\
\hline Morphotype 3 & $\begin{array}{l}\text { Shell double and thick, larvae usually present, with protru- } \\
\text { sion at one end similar to an operculum }\end{array}$ & $34 \times 19$ & \\
\hline Morphotype 4 & $\begin{array}{l}\text { Shell oval and thick, with rounded structure slightly pro- } \\
\text { truding at one end, may also be an operculum }\end{array}$ & $60 \times 47$ & \\
\hline Morphotype 5 & $\begin{array}{l}\text { Elliptical shape, shell thick, simple and smooth, larvae well } \\
\text { formed }\end{array}$ & $45.5 \times 26$ & \\
\hline Morphotype 6 & $\begin{array}{l}\text { Elliptical shape, shell transparent, thin and smooth, larvae } \\
\text { well formed }\end{array}$ & $58.5 \times 28$ & \\
\hline Morphotype 7 & $\begin{array}{l}\text { Barrel shape, shell smooth and relatively thick, dark brown, } \\
\text { different polar regions, only one operculum, embryonic mass } \\
\text { or larvae well developed }\end{array}$ & $35 \times 20$ & \\
\hline Morphotype 8 & $\begin{array}{l}\text { Round shape, medium size, shell smooth, thin, transparent, } \\
\text { embryonic mass present }\end{array}$ & $72 \times 51$ & \\
\hline
\end{tabular}


of nematodes that parasitize all classes of vertebrates around the world (ANDERSON, 2000; GIBSON, 2012; STAPF et al., 2013).

In the last 100 years, three taxonomic inventories of parasites in mammals were conducted, resulting in 13 superfamilies reported for the nematofauna of $C$. thous in Brazil (VICENTE et al., 1997; VIEIRA et al., 2008; PINTO et al., 2011). Among the nematodes that comprise the nematofauna of $C$. thous, the members of the superfamily Ancylostomatoidea were the most representative in terms of number of species, such as Uncinaria carinii Travassos, 1915, Ancylostoma buckleyi Le Roux \& Biocca, 1957, Ancylostoma caninum Ercolani, 1859, Ancylostoma braziliense Faria, 1910, and Ancylostoma sp. In addition to nematode adults, two egg morphotypes were found, as well as individuals that were not identified to the specific taxonomic level; although, they had features of this superfamily.

In Brazil, superfamily Trichinelloidea is represented by two families, (Trichuridae and Capillariidae), three genera (Trichuris, Capillaria, Pearsonema) and the following four species: Trichuris vulpis Froelich, 1789, a parasite of the cecum of the large intestine in host from Mato Grosso do Sul and Paraíba sates (VIEIRA et al., 2008; LIMA 2009; PINTO et al., 2011; CURI et al., 2010; LIMA et al., 2013); Pearsonema linsi Freitas \& Lent, 1935 and Pearsonema feliscati Diesing, 1851, parasites of the urinary bladder in host from Rio de Janeiro state (VIEIRA et al., 2008); and C. hepatica, a parasite of the liver in host from Rio Grande do Sul state (RUAS et al., 2003). In addition, Capillaria sp. occurs in different states of Brazil: Rio Grande do Sul (RUAS, 2005; RUAS et al., 2008), Paraná (SNAK et al., 2017) and Minas Gerais (CURI et al., 2010).

This is the first report of a Capillaria infection in the tongue of $C$. thous in Brazil, but the occurrence of capillariids in the tongue of mammals has already been reported for other countries. Copland (1975) reports that C. papuensis parasitizes the tongue of Sus scrofa papuensis in Papua New Guinea. Scapino \& Murphy (1978) describe the infection of the mucous membranes of the oral cavity of Procyon lotor, and suggests that the parasite is possibly Capillaria procyonis. Snyder $(1988,1989)$ reports the occurrence of eggs of C. procyonis in the tongue of Procyon lotor; both accounts were for Illinois, in the United States. Capillaria garfiai is reported to parasitize the tongue of wild Sus scrofa in Spain (FERRER \& CASTELLÀ, 1996).

Löwenstein \& Kutzer (1989) reported C. garfiai in wild boar in Austria, found a prevalence of $69 \%$ based on histopathological studies, and demonstrated that parasitism by $C$. garfiai in the tongue of this animal produces small pathological changes in the lingual tissue, which is different from what is reported in this article, since the nematodes did not cause injury.

In Brazil, parasitism by capillariids includes different species of parasites and hosts, and $C$. hepatica is the most commonly cited in the literature as a parasite of wild animals, such as those found in Sciurus aestuans (FREITAS \& LENT, 1936), Rattus norvegicus (ARAUJO, 1967; GALVÃO, 1981). Rattus rattus (CHIEFFI et al., 1981), dogs and cats (SILVEIRA et al., 1975), Tayassu tajacu (MANDORINO \& REBOUÇAS, 1991), Chrysocyon brachyurus (VICENTE et al., 1997) and Lycalopex gymnocercus (RUAS et al., 2003). Eggs of $C$. hepatica were found in insects (SOLOMON \& HANDLEY, 1971; FARHANG-AZAD, 1977). Lima et al. (2008) reported the occurrence of eggs of Capillaria spp. in the filet of Pseudupeneus maculatus Bloch, 1793, a fish sold in the metropolitan region of Recife, Pernambuco state, and noted the zoonotic potential of the genus and the need for more hygienic and sanitary control of the quality of the product offered to the consumer.

For C. thous, Ruas et al. (2003) reported the first case of parasitism of $C$. hepatica in the state of Rio Grande do Sul. In the state of Pará, Moreira et al. (2013) describes parasitism by $C$. hepaticum in synanthropic rodents $R$. norvegicus and $R$. rattus. Although Moravec (1982) included $C$. hepatica in the genus Calodium (Calodium hepaticum), this name is rarely used, and many authors place it in Capillaria.

The site of infection of the capillariids reported in this study is possibly an erratic occurrence in the cycle of this parasite, and the hosts acquired the infection due to certain habits, such as licking the genitals and anus of other animals in the same pack. The life cycle of capillariids is monoxenic and the infection occurs by ingestion of infective eggs after death (e.g., due to cannibalism or predation) and decomposition of the host (FARHANG-AZAD \& SCHLITTER, 1978; KATARANOVSKI et al., 2010).

The presence of capillariids in $C$. thous and other wild canids is possibly related to their diet, which includes wild and urban rodents, and is often influenced by habitat loss and the ease of obtaining food close to urban centers. Ruas et al. (2003) describes capillariids as parasites of the hepatic parenchyma and urinary bladder of multiple hosts, which are most commonly found in rodents, especially rats. Pedó et al. (2006) describe $C$. thous as a versatile predator and that small rodent species are the most important food item in its diet, with a $52.8 \%$ relative frequency, including at least seven species from distinct habits, such as open areas (Cavia aperea Erxleben, 1777), semi-aquatic (Holochilus brasiliensis Desmarest, 1819), cursorial in forest and open areas (Akodon sp.), semi-arboreal (Oligoryzomys sp.), arboreal (Phyllomys dasythrix Hensel, 1872), semi-fossorial in forest and open areas (Oxymycterus sp.) and peridomiciliary (Mus musculus Linnaeus, 1758). Birds, insects and fruits, as well as consuming the most abundant food resources in each season, have also been reported (BISBAL \& OJASTI, 1980; BERTA 1987; MOTTA-JUNIOR et al., 1994).

\section{Conclusions}

The presence of eggs and nematodes of Capillaria sp. in the tongue of $C$. thous is extremely important, not only as a public health issue, but to the knowledge of the biodiversity of zoonotic parasites present in wild populations of canids. However, an explanation of why the eggs and nematodes were in the epithelial and connective tissues of the tongue remains unclear since, until now, this has not been observed in the biological cycle of the species. Parasitism of $C$. thous by capillariids in Pará state requires a more detailed investigation into the circumstances of this finding, in order to obtain adults for morphological and molecular analyses that can elucidate the epidemiological implication of this parasitism and the potential zoonotic factor of this species, as well as to determine the wild rodents that can serve as reservoirs for the parasite. 


\section{Acknowledgements}

The authors are grateful to the following the Laboratório de Histologia e Embriologia Animal and Laboratório de Microscopia Eletrônica de Varredura - Instituto da Saúde e Produção Animal - Universidade Federal Rural da Amazônia - UFRA, campus Belém, state of Pará, Brazil for the use of the scanning electron microscope. This study is part of the Ph.D. thesis of Raul Henrique da Silva Pinheiro, developed for the Programa de Pós-Graduação em Biologia de Agentes Infecciosos e Parasitários, Instituto de Ciências Biológicas, Universidade Federal do Pará-UFPA. This study was financed in part by the Coordenação de Aperfeiçoamento de Pessoal de Nível Superior - Brasil (CAPES) - Finance Code 001", Ministério da Educaçáo do Brasil.

\section{References}

Anderson RC. Nematode parasites of vertebrates. Their development and transmission. 2nd ed. Wallingford: CABI Publishing; 2000. http://dx.doi. org/10.1079/9780851994215.0000.

Araújo P. Helmintos de Rattus norvegicus (Berkenhout, 1769) da cidade de São Paulo. Rev Fac Farm Bioquím S Paulo 1967; 5(1): 141-159.

Ascensão F, Mira A. Impactes das Vias Rodoviárias na Fauna Silvestre Universidade de Évora. Portugal [online]. 2006 [cited 2017 Aug 28]. Available from: https://www.infraestruturasdeportugal.pt/sites/default/ files/miraascensao_impactes_das_vias_rodoviarias_n.pdf

Berta A. Origin, diversification, and zoogeography of the South American Canidae. In: Patterson BD, Timm RM. Studies in neotropical mammalogy: essays in honor of Philip Hershkovitz. Chicago: Field Museum of Natural; 1987. Fieldiana Zoology New Series. p. 455-471.

Bisbal FJ, Ojasti JD. Nicho trófico del zorro Cerdocyon thous (Mammalia, Carnivora). Acta Biol Venez 1980; 10(4): 469-496.

Brandão ML, Chame M, Cordeiro JL, de Miranda Chaves SA. Diversidade de helmintos intestinais em mamíferos silvestres e domésticos na Caatinga do Parque Nacional Serra da Capivara, Sudeste do Piauí, Brasil. Rev Bras Parasitol Vet 2009;18(Suppl 1): 19-28. http://dx.doi.org/10.4322/ rbpv.018e1004. PMid:20040186.

Brandão ML. Helmintos de mamiferos da região do Parque Nacional da Capivara, sudeste do Piaui: diversidade e influências antrópicas [dissertação]. Rio de Janeiro: Escola Nacional de Saúde Pública, Fundação Oswaldo Cruz; 2007.

Chame M. Estudo comparativo das fezes e coprólitos não humanos da região arqueológica de São Raimundo Nonato Sudeste do Piaui [dissertação]. Rio de Janeiro: Universidade Federal do Rio de Janeiro; 1988.

Chieffi PP, Dias RMDS, Mangini ACS, Grispino DMA, Pacheco MAD. Capillaria hepatica (Bancroft, 1893) em murídeos capturados no Município de São Paulo, SP, Brasil. Rev Inst Med Trop São Paulo 1981; 23(4): 143-146. PMid:7323599.

Copland JW. Capillaria infections of pigs: description of C. papuensis sp. n. and the pathology of natural infections. J Helminthol 1975; 49(3): $187-$ 190. http://dx.doi.org/10.1017/S0022149X00023622. PMid:1184946.

Curi NHA, Araújo AS, Campos FS, Lobato ZIP, Gennari SM, Marvulo MFV, et al. Wild canids, domestic dogs and their pathogens in Southeast Brazil: disease threats for canid conservation. Biodivers Conserv 2010; 19(12): 3513-3524. http://dx.doi.org/10.1007/s10531-010-9911-0.
Curi NHA. Avaliação do estado de saúde e do risco de transmissão de doenças entre canídeos (Mammalia, Carnivora) silvestres e domésticos na regiāo da Serra do Cipó, Minas Gerais: implicaçôes para a conservação [dissertação]. Belo Horizonte: Pontifícia Universidade Católica; 2005.

Duarte FH, Vieira FM, Louzada GL, Bessa ECA, Souzalima S. Occurrence Angiostrongylus vasorum (Baillet, 1866) (Nematoda: Angiostrongylidae) in Cerdocyon thous Linnaeus, 1766 (Carnivora: Canidae) in Minas Gerais State, Brazil. Arq Bras Med Vet Zootec 2007; 59(4): 1086-1088. http:// dx.doi.org/10.1590/S0102-09352007000400042.

Duarte HF. Helmintofauna em Cerdocyon thous Linnaeus, 1766 (Carnivora, Canidae) na região de Juiz de Fora, Minas Gerais [dissertação]. Juiz de Fora: Universidade Federal de Juiz de Fora; 2007.

Farhang-Azad A, Schlitter DA. Capillaria hepatica in small mammals collected from Shoa province, Ethiopia. J Wildl Dis 1978; 14(3): 358 361. http://dx.doi.org/10.7589/0090-3558-14.3.358. PMid:691131.

Farhang-Azad A. Ecology of Capillaria hepatica (Bancroft 1893) (Nematoda). II. Egg-releasing mechanisms and transmission. J Parasitol 1977; 63(4): 701-706. http://dx.doi.org/10.2307/3279576. PMid:560449.

Ferreira JA Jr, Blume GR, Sousa SKH, Carvalho CM, Gardiner C. Anatomo-pathological aspects of parasitism by nematodes of the superfamily Metastrongyloidea in wild crab-eating fox (Cerdocyon thous) in Midwestern Brazil. Cienc Rural 2017; 47(2): 1-4. http://dx.doi. org/10.1590/0103-8478cr20160547.

Ferrer D, Castellà J. Capillaria garfiai Gallego et Mas-Coma, 1975 (Nematoda: Trichuridae) in a wild boar in Catalonia, Spain. Res Rev Parasitol 1996; 56(1): 65-67.

Freitas FJ, Lent H. Estudo sobre os Capillariinae parasitos de mammiferos (Nematoda: Trichuroidea). Mem Inst Oswaldo Cruz 1936; 31(1): 85-160. http://dx.doi.org/10.1590/S0074-02761936000100006.

Fuehrer HP. An overview of the host spectrum and distribution of Calodium hepaticum (syn. Capillaria hepatica): part 2-Mammalia (excluding Muroidea). Parasitol Res 2014; 113(2): 641-651. http://dx.doi. org/10.1007/s00436-013-3692-9. PMid:24257974

Galvão VA. Estudos sobre Capillaria hepatica: uma avaliação do seu papel patogênico para o homem. Mem Inst Oswaldo Cruz 1981; 76(4): 415-433. http://dx.doi.org/10.1590/S0074-02761981000400010. PMid:6757648.

Gibson D. Fauna Europaea: Capillariidae [online]. 2012 [cited 2017 Sep 10]. Available from: www.faunaeur.org

Gomes APN, Olifiers N, Santos MM, Simôes RO, Maldonado A Jr. New records of three species of nematodes in Cerdocyon thous from the Brazilian Pantanal wetlands. Rev Bras Parasitol Vet 2015; 24(3): 324-330. http://dx.doi.org/10.1590/S1984-29612015061. PMid:26444063.

Griese J. Helmintofauna de vertebrados atropelados em rodovias da região de Botucatu, São Paulo [dissertação]. Botucatu: Universidade Estadual Paulista; 2007.

Grisi L. Ocorrência de Angiocaulus raillieti (Travassos, 1927) comb. n. em Canis familiaris L. (Hematoda: Protostrongylidae). Rev Bras Biol 1971; 31(1): 27-32.

Guardone L, Deplazes P, Macchioni F, Magi M, Mathis A. Ribosomal and mitochondrial DNA analysis of Trichuridae nematodes of carnivores and small mammals. Vet Parasitol2013; 197(1-2):364-369. http://dx.doi. org/10.1016/j.vetpar.2013.06.022. PMid:23920054.

Hoppe EGL, Araújo de Lima RC, Tebaldi JH, Nascimento AA. Pterygodermatites (Multipectines) pluripectinata n. sp. (Spirurida: Rictulariidae), a nematode parasite of the crab-eating fox Cerdocyon thous (Linnaeus, 1766) from 
Caatinga shrubland, Brazil. J Helminthol 2010; 84(3): 312-316. http:// dx.doi.org/10.1017/S0022149X0999071X. PMid:20056009.

Kataranovski M, Zolotarevski L, Belij S, Mirkov I, Stošić J, Popov A, et al. First record of Calodium hepaticum and Taenia taeniaeformis liver infection in wild norway rats (Rattus norvegicus) in Serbia. Arch Biol Sci 2010; 62(2): 431-440. http://dx.doi.org/10.2298/ABS1002431K.

Lafferty KD. Environmental parasitology: What can parasites tell us about human impacts on the environment? Parasitol Today 1997; 13(7): 251-255. http://dx.doi.org/10.1016/S0169-4758(97)01072-7. PMid:15275061.

Lima MM, Teixeira WC, Ramos RAN, Lima AMA, Alves LC, Faustino MAG. Occurrence of eggs of Capillaria sp. in filet of fish Saramunete (Pseudupneus maculatus) marketed in the Metropolitan Area of Recife-PE/ Brazil. Med Vet 2008; 2(1): 35-37.

Lima RC, Hoppe EGL, Tebaldi JH, Cruz BC, Gomes AAB, Nascimento AA. Gastrintestinal helminths of Cerdocyon thous (Linnaeus, 1766 Smith, 1839) from the caatinga area of the Paraíba State, Brazil. Semina: Ciênc Agrár 2013; 34(6): 2879-2888. http://dx.doi.org/10.5433/1679$0359.2013 \mathrm{v} 34 \mathrm{n} 6 \mathrm{p} 2879$.

Lima RCA. Helmintos gastrintestinais de Cerdocyon thous (Linnaeus, 1766) Smith, 1839 provenientes da área de caatinga do Estado da Paraiba, Brasil [dissertação]. Jaboticabal: Universidade Estadual Paulista; 2009.

Löwenstein M, Kutzer E. Die Capillarien (Nematoda: Trichuridae) des Wildschweines (Sus scrofa) in Osterreich. Angew Parasitol 1989; 30(4): 221-237. PMid:2596728.

Malheiros R. A rodovia e os corredores da fauna dos cerrados. Goiânia: Ed. UCG; 2004.

Mandorino L, Rebouças MM. Capilaríase hepática em caititu - Tayassu tajacu (L.). Arq Inst Biol São Paulo 1991; 58(1-2): 61-62.

Moraes MFD. Estudos parasitológicos em cães domésticos errantes e carnivoros selvagens generalistas no Parque Nacional do Iguaçu, Foz do Iguaçu [dissertação]. Jaboticabal: Universidade Estadual Paulista; 2016.

Moravec F. Proposal of a new systematic arrangement of nematodes of the family Capillariidae. Folia Parasitol (Praha) 1982; 29(2): 119-132. PMid:7106653.

Moreira VLC, Giese EG, Baía da Silva DC, Melo FTV, Furtado AP, Maldonado A Jr, et al. Calodium hepaticum (Nematoda: Capillariidae) in synanthropic rodents (Rattus norvegicus and Rattus rattus) in Eastern Amazonia. Rev Bras Parasitol Vet 2013; 22(2): 265-269. http://dx.doi. org/10.1590/S1984-29612013000200046. PMid:23856730.

Motta-Junior JC, Lombardi JA, Talamoni SA. Notes on crab-eating fox (Dusicyon thous) seed dispersal and food habits in southeastern Brazil. Mammalia Paris 1994; 58(1): 156-159.

Noronha D, Bragança R, Vicente JJ, Pereira LCM. Coleções particulares incorporadas à Coleçáo Helmintológica do Instituto Oswaldo Cruz (CHIOC). I: Coleção do Instituto Pasteur de São Paulo. Rev Bras Zool 2004; 21(2): 303-305. http://dx.doi.org/10.1590/S0101-81752004000200023.

Noronha D, Vicente JJ, Pinto RM. A survey of new records for nematodes from mammals deposited in the Helminthological Collection of the Oswaldo Cruz Institute (CHIOC). Rev Bras Zool 2002; 19(3): 945-949.

Pedó E, Tomazzoni AC, Hartz SM, Christoff AU. Diet of crab-eating fox, Cerdocyon thous (Linnaeus) (Carnivora, Canidae), in a suburban area of southern Brazil. Rev Bras Zool 2006; 23(3): 637-641. http://dx.doi. org/10.1590/S0101-81752006000300005.
Pinowski J. Roadkills vertebrates in Venezuela. Rev Bras Zool 2005; 22(1): 191-196. http://dx.doi.org/10.1590/S0101-81752005000100023.

Pinto RM, Knoff M, Gomes DC, Noronha D. Nematodes from Mammals in Brazil: an updating. Neotrop Helminthol 2011; 5(2): 139-183.

Prada CS. Atropelamento de vertebrados silvestres em uma regiāo fragmentada do nordeste do estado de São Paulo: quantificação do impacto e análise dos fatores envolvidos [dissertação]. São Carlos: Universidade Federal de São Carlos; 2004.

Ribeiro CT, Verocai GG, Tavares LER. Dioctophyme renale (Nematoda, Dioctophymatidae) infection in the Crab-eating Fox (Cerdocyon thous) from Brazil. JWildl Dis 2009; 45(1): 248-250. http://dx.doi.org/10.7589/00903558-45.1.248. PMid:19204359.

Richini-Pereira VB, Griese J, Bosco SMG, Silva RJ, Bagagli E. Road-killed wild animals: use in molecular eco-epidemiology of fungal pathogens. $J$ Venom Anim Toxins Incl Trop Dis 2006; 12(4): 674.

Ruas JL, Muller G, Farias NAR, Gallina T, Lucas AS, Pappen FG, et al. Helmintos do cachorro do campo, Pseudalopex gymnocercus (Fischer, 1814) e do cachorro do mato, Cerdocyon thous (Linnaeus, 1766) no sul do Rio grande do Sul, Brasil. Rev Bras Parasitol Vet 2008; 17(2): 87-92. http:// dx.doi.org/10.1590/S1984-29612008000200005. PMid:18823576.

Ruas JL, Soares MP, Farias NAR, Brum JGW. Infecção por Capillaria hepatica em carnívoros silvestres (Lycalopes gymnocercus e Cerdocyon thous) na regiāo sul do Rio Grande do Sul. Arq Inst Biol (Sao Paulo) 2003; 70(2): 147-150.

Ruas JL. Caracterização da fauna parasitária do Pseudalopex gymnocercus (Graxaim-do-Campo) e do Cerdocyon thous (Graxaim-do-Mato) na região sul do Rio Grande do Sul [tese]. Porto Alegre: Universidade Federal do Rio Grande do Sul; 2005.

Santos JDO. Estudo de formas embrionárias de helmintos encontradas em fezes de Cerdocyon thous (Linnaeus, 1766) no Parque nacional da Serra da Capivara, sudeste do Piaui [monografia]. Rio de Janeiro: Universidade Gama Filho; 2008a.

Santos JLC. Parasitos de canídeos domésticos e silvestres da regiāo do Parque Nacional da Serra do Cipó - Minas Gerais, Brasil [dissertação]. Belo Horizonte: Universidade Federal de Minas Gerais; 2008b.

Santos JDO. Diversidade de helmintos intestinais em cães domésticos (Canis familiaris Linnaeus, 1758) e de raposas (Cerdocyon thous Linnaeus, 1766) no semiárido do Nordeste do Brasil e implicaçôes para a saúde [dissertação]. Rio de Janeiro: Escola Nacional de Saúde Pública, Fundação Oswaldo Cruz; 2013.

Santos JLC, Magalhães NB, Santos HA, Ribeiro RR, Guimarães MP. Parasites of domestic and wild canids in the region of Serra do Cipó National Park, Brazil. Rev Bras Parasitol Vet 2012; 21(3): 270-277. http:// dx.doi.org/10.1590/S1984-29612012000300016. PMid:23070438.

Santos KR, Catenacci LS, Pestelli MM, Takahira RK, Lopes RS, Silva RJ. First report of Ancylostoma buckleyi Le Roux and Biocca, 1957 (Nematoda: Ancylostomatidae) infecting Cerdocyon thous Linnaeus, 1766 (Mammalia: Canidae) from Brazil. Rev Bras Parasitol Vet 2003; 12(4): 179-181.

Santos KR, Catenacci LS, Pestelli MM, Takahira RK, Silva RJ. First report of Diphyllobothrium mansoni (Cestoda, Diphyllobothridae) infecting Cerdocyon thous (Mammalia: Canidae) in Brazil. Arq Bras Med Vet Zootec 2004; 56(6): 796-798. http://dx.doi.org/10.1590/S010209352004000600016.

Santos PMS, Silva SGN, Fonseca CF, Oliveira JB. Parasites of birds and mammals in captivity in Pernambuco state, Brazil. Pesq Vet Bras 2015; 35(9): 788-794. http://dx.doi.org/10.1590/S0100-736X2015000900004. 
Scapino RP, Murphy RA. Nematode from the Masticatory Mucosa of the Raccoon (Procyon lotor). Vet Pathol 1978; 15(1): 136-137. http://dx.doi. org/10.1177/030098587801500116. PMid:625864.

Silveira D, Nogueira RHG, Silva JML, Nascimento EF, Lúcio WF. Sobre um caso de capilariose hepática em cão. Arq Esc Vet UFMG 1975; 27(2): $231-234$

Snak A, Agostini KM, Lenzi PF, Montanucci CR, Delgado LE, Zabott MV. Perfil parasitológico de mamíferos silvestres cativos. Vet Zootec 2017; 24(1): 193-200

Snyder DE. Capillaria procyonis (Nematoda: Trichuroidea) eggs from the tongue of the raccoon (Procyon lotor). J Wildl Dis 1988; 24(4): 722 723. http://dx.doi.org/10.7589/0090-3558-24.4.722. PMid:3193575.

Snyder DE. New Information on the location of Capillaria procyonis (Nematoda: Trichuroidea) in the tongue of a raccoon (Procyon lotor). $J$ Wildl Dis 1989; 25(2): 294-296. http://dx.doi.org/10.7589/0090-355825.2.294. PMid:2716115.

Solomon GB, Handley CO Jr. Capillaria hepatica (Bancroft, 1893) in Appalachian Mammals. J Parasitol 1971; 57(5): 1142-1144. http://dx.doi. org/10.2307/3277883. PMid:5133894.

Stapf AN, Kavetska KM, Ptak PP, Rząd I. Morphometrical and ecological analysis of nematodes of the family Capillariidae (Neveu-Lemaire, 1936) in wild ducks (Anatinae) from the north-western Poland. Ann Parasitol 2013; 59(4): 195-201. PMid:24791347.

Travassos L, Freitas JFT. Relatório da sétima excursão científica do Instituto Oswaldo Cruz, realizada á zona da Estrada de Ferro Noroeste do Brasil, em maio de 1942. Mem Inst Oswaldo Cruz 1943; 38(3): 385-412. http:// dx.doi.org/10.1590/S0074-02761943000300007.

Travassos L, Pinto C, Muniz J. Excursão scientifica ao Estado de Matto Grosso na Zona do Pantanal (margens dos rios S. Lourenço e Cuyabá) realizada em 1922. Mem Inst Oswaldo Cruz 1927; 20(2): 249-269. http:// dx.doi.org/10.1590/S0074-02761927000200004.

Travassos L. Uncinaria carinii n. sp. (nota prévia). Braz Med 1915; 29(10): 79-80.

Vicente JJ, Rodrigues HO, Gomes DC, Pinto RM. Nematóides do Brasil. Parte V: Nematóides de mamíferos. Rev Bras Zool 1997; 14(Suppl 1): 1-452. http://dx.doi.org/10.1590/S0101-81751997000500001.

Vieira FM, Luque JL, Muniz-Pereira LC. Checklist of helminth parasites in wild carnivore mammals from Brazil. Zootaxa 2008; 1721: 1-23.

Vieira FM. Helmintos parasitos de mamiferos carnivoros silvestres no Município de Juiz de Fora, Zona da Mata do Estado de Minas Gerais, Brasil [tese]. Juiz de Fora: Universidade Federal de Juiz de Fora; 2011. 